\title{
Socio-Economic Analysis of Effectiveness of Implementation of an Employment Guarantee Scheme at Local Level: A Study of a Village in India
}

https://doi.org/10.21272/sec.4(2).23-30.2020

Sanjeet Mahapatra, ORCID: https://orcid.org/0000-0002-6622-5478

Graduate Scholar, Xavier University, Bhubaneshwar, India

Anand Pandey, ORCID: https://orcid.org/0000-0001-8460-8475

Founder, Fundamental Action and Research Foundation, Bengaluru, India

Badri Narayanan, ORCID: https://orcid.org/0000-0001-9628-8173

PhD, Economist, School of Environment and Forestry Sciences, University of Washington Seattle, USA

\begin{abstract}
The main purpose of the study is to develop theoretical and practical principles for analyzing the economic efficiency of the program to guarantee employment in rural areas in India. This program of support and active promotion of employment of the rural population is the result of the adoption of the Law on Guarantees of Employment in Rural Areas. The relevance of the choice of this scientific problem is that most scientific papers focus on assessing the effectiveness of the implementation of this legal act at the macro level, while the article analyzes this issue at the level of a particular locality. The object of the study was the village of Sanatpur in Uttar Pradesh, India. The study conducted a survey of participants in the program to guarantee employment in this rural area, which served as a basis for primary data, as well as used official statistics on the implementation of this program in the country. Descriptive statistics methods were used to analyze the effectiveness of the program to guarantee employment in rural areas. The article analyzes the mechanism of implementation of the program to guarantee employment in rural areas, namely the peculiarities of job creation in rural areas, the formation of wage policy, as well as the payment of wages to local residents. The field study identified key difficulties in implementing the above program: insufficient awareness of villagers about the opportunities and benefits of participating in the approved employment support program, as well as low access to basic financial services and lack of almost $70 \%$ of the rural population individual bank accounts. The results of the study can be useful for local and national governments in the field of social protection and social security.
\end{abstract}

Keywords: decentralized planning, wage payment, job guarantee.

JEL Classification: J01.

This work is licensed under a Creative Commons Attribution 4.0 International License.

Cite as: Mahapatra, S., Pandey, A., Narayanan, B. (2020). Socio-Economic Analysis of Effectiveness of Implementation of an Employment Guarantee Scheme at Local Level: A Study of a Village in India. SocioEconomic Challenges, 4(2), 23-30. https://doi.org/10.21272/sec.4(2).23-30.2020.

(C) The Authors, 2020. This article is published with open access at Sumy State University.

\section{Introduction}

The main aim of this paper is to study the implementation of MGNREGA at Sanathpur village in UP. While there have been several studies on the broad topic of MGNREGA (see some summarized in Government of India (2012), Gupta et al (2017), Bishnoi et al (2012), Gupt (2015), World Bank (2008) and Sathishkumar and Kumar (2020), for example), there has been a dearth of local-oriented study that clearly identifies the socioeconomic issues from a primary field study perspective. Our paper attempts at filling this gap in literature.

The aim of MGNREGA is to provide income protection to the families living in rural areas by providing each household, whose adult members are ready to do unskilled labour, a maximum of one hundred days of work. 
Since, the last six months, there have been reports of lack of funds to implement the act. We undertook a survey of the workers involved to study the direct and indirect impacts of shortage of funds.

The objective of our study is to throw lights on the following points:

$>$ Last five years fund allocation to MGNREGA. Is there any reduction in this fiscal year? If not, why five states have finished their budget for MNREGA for the current fiscal year? These include Andhra Pradesh, Uttar Pradesh and West Bengal.

$>$ How much work done planned in 2017-2018, accomplished \& pending in the current year?

$>$ For accomplished work, what percentage of wages has been disbursed and what percentage is pending?

$>$ In case of delay in wage payment, what reason has been cited to workers?

$>$ Due to delay in wages payment, what is impact on trust and labour availability for upcoming works?

$>$ Other abnormalities \& observation in MNREGA.

\section{Methodology}

The study is based in Sanathpur village of Suriyawan block of Bhadohi district.

The primary information was gathered from the adults of the village who have registered themselves in MGNREGA. The workers belong to either scheduled caste or other backward classes. They are spread over three areas inside the village - Bind Basti, Harijan Basti and Maurya Basti.As our study was focussed on Sanathpur village of Suriyawan bloc,Weinterviewed workers from the Bind Basti and Harijan Basti mostly as some part of the Maurya Basti belong to other block.

The questions that were asked during the survey:

$>$ Basic questions - Name, age;

$>$ Whether you have worked in the year 2017-18;

$>$ No. of days worked;

$>$ Whether wage has been paid or not. Is there any delay in the payment of wage;

$>$ How much amount has been paid.

The secondary information was extracted from the official website of the act, i.e. http://www.nrega.nic.in/netnrega/home.aspx. We have based our findings based on the information that We got from the above website. The findings We got by interviewing the workers are noted out in the abnormalities section of this report.

\section{About MGNREGA}

MGNREGA is an Indian legislation enacted on August 25, 2005. The act provides legal guarantee of one hundred days of work to every adult member of each household, provided they are ready to do unskilled labour. The act was introduced with an aim to improve the purchasing power of the poor living in the rural areas and making them financially secure.

\subsection{Features:}

$>$ Legal right to work: This Act provides a legal right to employment for adult members of rural households. At least one third beneficiaries have to be women. At present, wage rates are determined by the central government but vary across states, ranging from Rs. 135 per day to Rs. 214 per day.

$>$ Time bound guarantee of work and unemployment allowance: Employment must be provided with 15 days of being demanded failing which an 'unemployment allowance' must be given.

$>$ Decentralised planning: Gram Sabhas must recommend the works that are to be undertaken and at least $50 \%$ of the works must be executed by them. PRIs are primarily responsible for planning, implementation and monitoring of the works that are undertaken.

$>$ Work site facilities: All work sites should have facilities such as crèches, drinking water and first aid.

> Transparency and accountability: There are provisions for proactive disclosure through wall writings, citizen information boards, Management Information Systems and social audits. Social audits are conducted by Gram Sabhas to enable the community to monitor the implementation of the scheme. 
Funding: Funding is shared between the centre and the states. There are three major items of expenditure - wages (for unskilled, semi-skilled and skilled labour), material and administrative costs. The central government bears $100 \%$ of the cost of unskilled labour, $75 \%$ of the cost of semi-skilled and skilled labour, $75 \%$ of the cost of materials and $6 \%$ of the administrative costs.

\subsection{Objectives of MGNREGA}

$>$ Expanding earning sources.

$>$ Strengthening pure natural resources under control via works that deal with causes of serious hardship like famine, deforestation and ground break down and so motivate maintainable growth.

$>$ Strengthening grassroots procedures of democracy.

$>$ Infusing visibility and responsibility in government.

$>$ Strengthening high decentralization as well as deepening procedures of democracy by providing a critical part to the local Panchayati Raj, Organizations in planning, tracking and execution.

\section{Jobs issued and distribution of workers based on Age, Caste and Gender}

\subsection{Registered households}

The total number of the households registered in MGNREGA in Sanathpur village is 141, which consists of 237 adult members. Out of these, 79 households are of SC category (with 150 adults) and 62 are of OBC category (with 87 adults). Only 35 out of 150 in SCs category and 15 out of 87 in OBCs category are active workers.

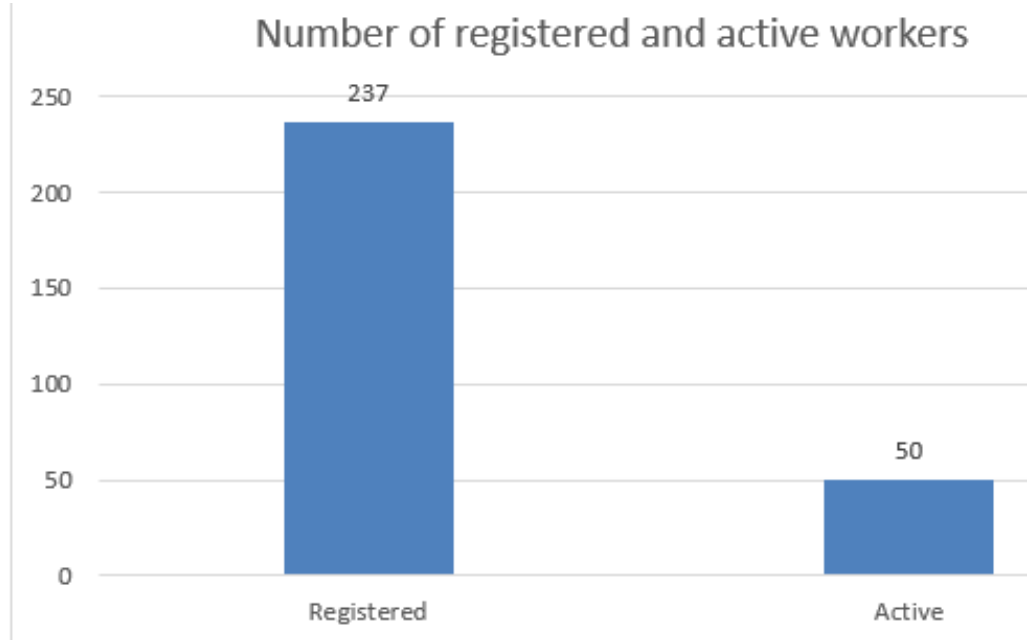

Figure 1. Number of registered and active workers

Source: Primary Data \& http://www.nrega.nic.in/netnrega/home.aspx

Percentage of registered and active workers

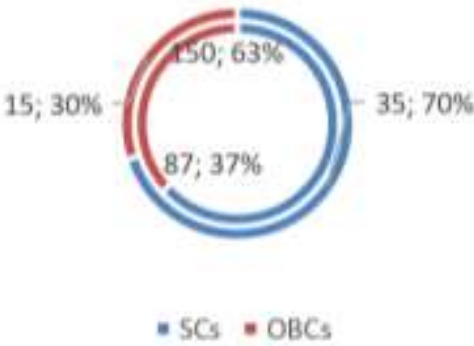

Figure 2. Percentage of registered and active workers

Source: Primary Data \& http://www.nrega.nic.in/netnrega/home.aspx

\subsection{Distribution of workers based and gender}

Out of a total of 237 workers, 69 are women, out of which only 18 are active workers. 


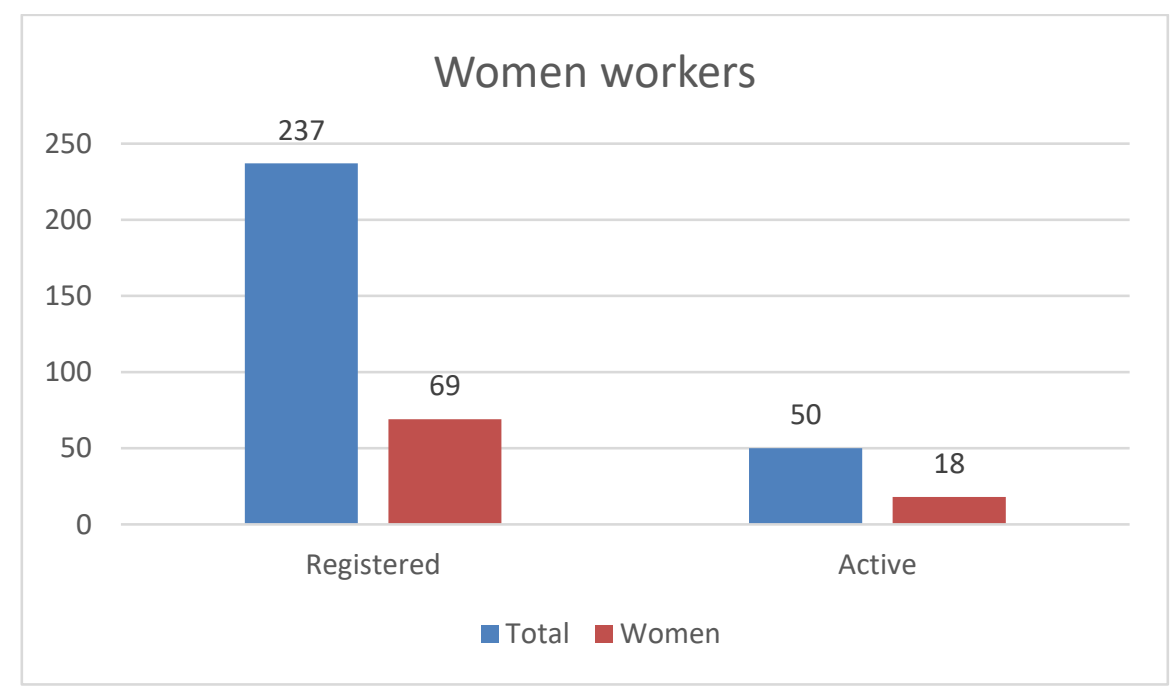

Figure 3. Women workers

Source: Primary Data \& http://www.nrega.nic.in/netnrega/home.aspx.

\subsection{Distribution of workers based on age group}

Majority of the workers registered are in the age group of 31-40 years. However, only 9 out of them have been employed in the current financial year.

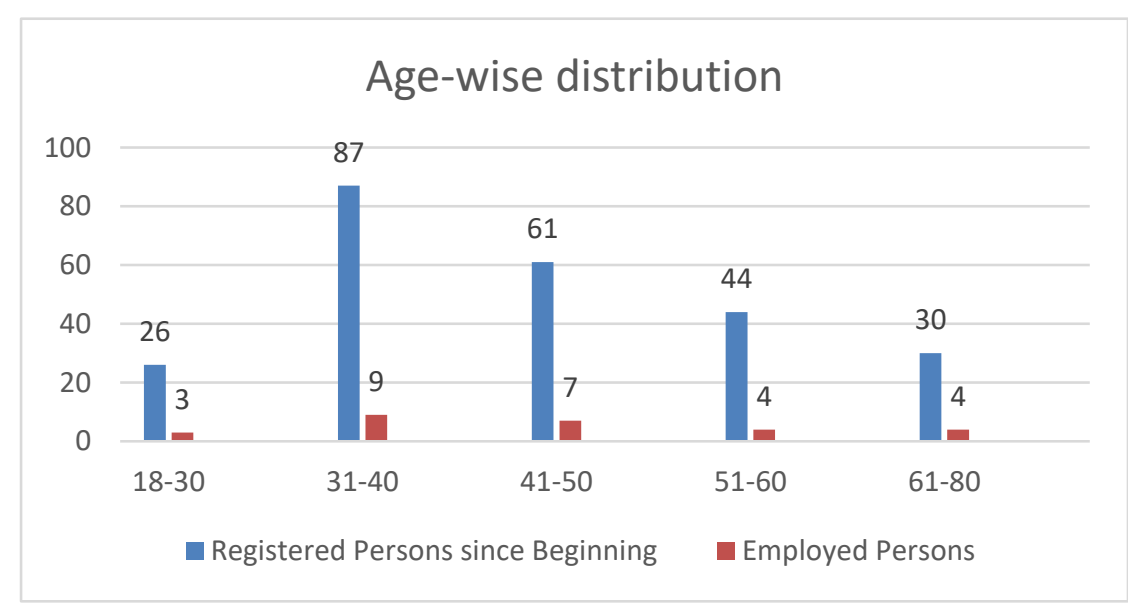

\section{Figure 4. Age-wise distribution}

Source: Primary Data.

\section{Demand and Allocation of work under MGNREGA}

\subsection{Status of households in the financial year 2017-18}

In the financial year 2017-18, out of 141 households, only 17 households and 28 adult members demanded and were allocated work.

Table 1. Number of registered housholds, work demanded and allocated

\begin{tabular}{|c|c|c|c|c|c|c|c|c|}
\hline & & \multicolumn{2}{|c|}{ No. of Registered } & \multicolumn{2}{c|}{ demanded } & \multicolumn{2}{|c|}{ Employment offered } & $\begin{array}{c}\text { Families } \\
\text { Completed }\end{array}$ \\
\hline S No. & Panchayats & Household & Persons & Household & Persons & Household & Persons & 100 days \\
\hline 1 & 2 & 3 & 4 & 13 & 14 & 15 & 16 & 20 \\
\hline 57 & SANATHPUR & 141 & 237 & 17 & 28 & 17 & 28 & 0 \\
\hline
\end{tabular}

Source: http://www.nrega.nic.in/netnrega/home.aspx.

5.2 Reason for low demand of work in the current financial year 
While interviewing the villagers in both the areas,Wenoticed one thing. All the people who have worked in the current financial year belong to Harijan Basti. People from the Bind Basti complained of the unavailability of work since the last two years or more than that.Another major reason for low demand for work can be attributed the fact that in the past the wage payment had been delayed and no compensation was given for the delay. This is not only the case for the people of this area. Even people from the Harijan Basti have faced the same problems and have faced them this year too. In the absence of any work, these villagers turn to daily labour jobs to feed themselves and their family.

\section{Work status in the current financial year}

The number of works approved in the financial year 2017-18 is 26 . Out of these numbers, 21 works are related to IAY. Out of the total number of works approved, only eight of them are under progress. It is interesting to know that four works are spilled over from the financial year 2015-16. Over all, out of the 26 approved works, currently 12 are under progress. The work completion rate as of 2017-18 financial year is zero till now. In comparison, in the financial year 2014-15, the total number of works started was 25 and all of them were completed in that year itself. In the year 2015-16, out of the six works that were started, two were completed in that year itself. Another important observation is the delay in the completion of the approved works. All the 12 on-going works are currently running more than three months behind the schedule.

Table 2. Ongoing and completed works

\begin{tabular}{|c|c|c|c|c|c|c|c|c|c|}
\hline \multirow{2}{*}{ Sn } & \multirow[b]{2}{*}{ Work Category Name/Work Sub Categeny Natee/Work Type } & \multicolumn{4}{|c|}{ Spillover+New } & \multirow{2}{*}{$\begin{array}{l}\text { No. of New } \\
\text { Works }\end{array}$} & \multirow[b]{2}{*}{ Unit. } & \multirow[b]{2}{*}{$\begin{array}{l}\text { Fatimated } \\
\text { Outcome }\end{array}$} & \multirow[b]{2}{*}{$\begin{array}{l}\text { Eotimated Cost } \\
\text { (tis Lakhs) }\end{array}$} \\
\hline & & $\begin{array}{l}\text { Tatol } \\
\text { Workt }\end{array}$ & \begin{tabular}{l|} 
Onpoing \\
works
\end{tabular} & $\begin{array}{l}\text { Completed } \\
\text { Works }\end{array}$ & Expendature & & & & \\
\hline & PUELIC WOHKS RELATIING TO WATTUEAL RESOURCTS RANAGEMENT & & & & & & & & \\
\hline 1 & Water Consenvation & of & 0 & क & 可 & 可 & Hec. & 可 & G \\
\hline$\frac{\pi}{2}$ & Waterahad managemant & of & a & है & a & a & Hect & a & c \\
\hline 3 & Inigetion & 2 & 1 & 6] & 0,16 & 0 & Hes:- & 6 & c \\
\hline 4 & Tradticool watter bodies & 可 & of & a & 可 & & Hec- & 可 & 6 \\
\hline 5. & Afforectation & of & c. & 8] & of & of & Hest. & to & G \\
\hline \multirow[t]{3}{*}{5} & Land developpinent & a & 0 & c] & (2) & t) & Hes: & b & ] \\
\hline & Sob Total & 2. & 1 & 0 & 0.16 & 0 & & & o \\
\hline & 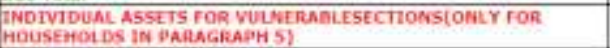 & & & & & & & & \\
\hline 7 & Impreving productivity of loots & 5 & 0 & a & D. & 0 & Mect & 0 & \\
\hline 8 & Improwisg live hooss thrsugh & 0 & a. & d & of & of & Hes: & a & 0 \\
\hline 9 & Develooment of falominacte lands & of & o: & d & 可 & of & Hect & a & c \\
\hline 10 & Canstruction of heuse & 25 & 11 & क] & 0.52 & 21 & Hois & g & G \\
\hline 11 & Promution of livestod & 0. & 0 & d & 0 & of & Hos. & 0 & 3 \\
\hline \multirow{3}{*}{12} & Promotion of fishesies & a. & 0 & a & 0 & 0 & Mos. & a & a \\
\hline & Subt Total & 30 & 11 & a & 0.52 & 21 & & & (1) \\
\hline & 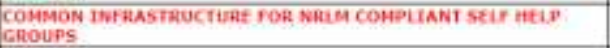 & & & & & & & & \\
\hline $13:$ & Agriculturs produdivay & d & of & ] & a & d] & mest & 古 & \\
\hline \multirow[t]{3}{*}{14} & Commsn wark-sheds for livelihoos activities of sef-helip proups & 0 & 0 & का & 6 & 0 & Hion. & 6 & 6 \\
\hline & Sob Total & of & 0 & 0 & की & 0 & & & to \\
\hline & BUIRAL INFRASTUCTUNE & & & & & & & & \\
\hline 15 & Rural taktation & d. & 号 & का & 贯 & d] & Nons. & to & \\
\hline 16 & Rogd connectivitv/lnterral ronda/Streets & a & 过 & a & 可 & 1 & KH. & อ & \\
\hline 17 & Piar teids & of & 0 & d] & 贯 & 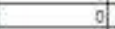 & Nosi & D & 0 \\
\hline 18 & Dsaater preparedieas/Restoration & of & of & a & 可 & of & Nos: & 可 & \\
\hline 19 & Construction of zuleng & की & to & (3) & a & of & hos- & t] & G \\
\hline 20 & Foot Gnin satorape structures & 0 & 可 & a & 再 & & Hor. & 0 & \\
\hline 21 & Probuction of bulding materalireguired for cocsthuction & if & of & a & of & of & Hos. & 0 & o \\
\hline 22 & Mantarianct & of & a) & e] & a & a & nines. & a & \\
\hline 23 & any blet wasks & 0 & 0 & क & 0 & 0 & thos. & 7 & \\
\hline & Seb Total & a & ef & 可 & 可 & 1 & & & to \\
\hline & Grand Total & 36 & 12) & क] & 0.60 & 22 & & & a \\
\hline
\end{tabular}

Source: http://www.nrega.nic.in/netnrega/home.aspx.

\section{Status of wages in the financial year 2017-18}

\subsection{Wages - Amount dispersed and pending}

The revised minimum wage for the state of Uttar Pradesh in 2017-18 is 175 INR.The total amount disbursed to the workers as wages is 84525 INR. This sums up to a total of 483 man-days. The payment includes those work which are yet not completed.

Although it is a good news that all the persons who worked this year got their wages, it is important to note that none of the workers got his or her payment on time. The delay varies from five days to 38 days. 25 percent or seven workers out of the 28 (those who worked in the current financial year) got their payment after 38 days. 


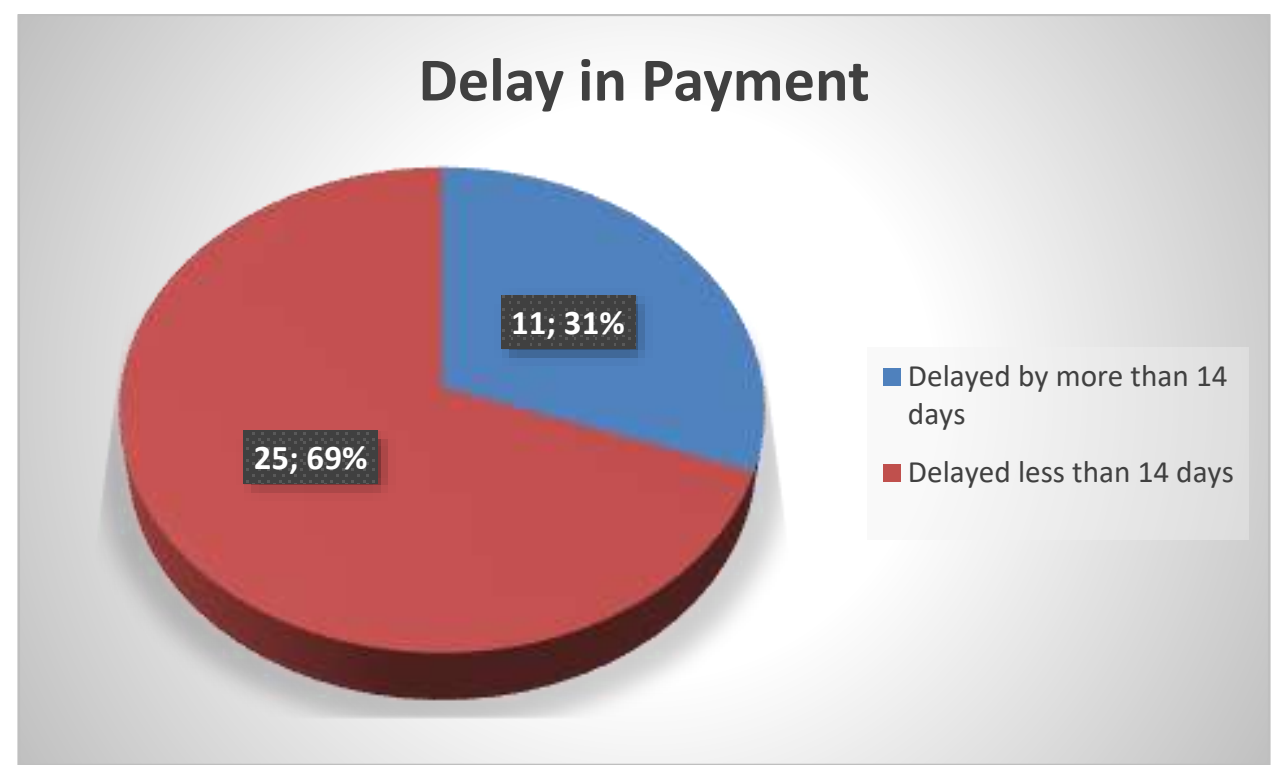

Figure 5. Delay in Payment

Source: Primary Data.

Now, as per the system of MGNREGA, a worker is entitled to receive a delay compensation at a rateof 0.05 percent of the total unpaid wages per day for the duration of the delay beyond the sixteenth day of the closure of the muster roll. However, on observing the entries made in the MIS portal, none of the workers whose wage payment got delayed by more than 15 days got delay compensation.

Table 3. Delay in payment

\begin{tabular}{|c|c|c|c|c|c|c|c|c|c|c|c|c|c|}
\hline \multirow[b]{2}{*}{$\begin{array}{l}3 x \\
0\end{array}$} & \multirow[b]{2}{*}{ Parchaje: } & \multicolumn{5}{|c|}{ De ar sd conpensation } & \multicolumn{5}{|c|}{ Fegation Peasorin Deps) } & \multirow[b]{2}{*}{$\begin{array}{c}\text { delayed compensation } \\
\text { Paid? In P5. }\end{array}$} & \multirow[b]{2}{*}{$\begin{array}{l}\text { Duzln } \\
\text { R5: }\end{array}$} \\
\hline & & $\begin{array}{c}\text { Payabeicin Deay } \\
\text { Dassi }\end{array}$ & 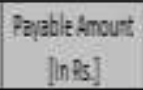 & $\begin{array}{c}\text { foproved (In Delay } \\
\text { Dars) }\end{array}$ & $\begin{array}{l}\text { Approied } \\
\text { Amount }\end{array}$ & $\begin{array}{c}\text { Amourtyetio be } \\
\text { lestited }\end{array}$ & $\begin{array}{c}\text { insuficent } \\
\text { fund }\end{array}$ & $\begin{array}{l}\text { Nlatural } \\
\text { Calamilies }\end{array}$ & $\begin{array}{l}\text { Compersation } \\
\text { not due }\end{array}$ & oth & $\begin{array}{c}\text { Tola Pajected } \\
\text { Days }\end{array}$ & & \\
\hline 1 & 2 & 8 & 4 & 5 & 6 & 7 & 8 & 9 & 10 & 11 & 12 & 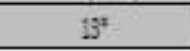 & $14-5-13$ \\
\hline 5 & ITHPUR & 477 & 202 & 0 & & & 0 & & & 393 & 477 & & \\
\hline
\end{tabular}

Source: http://www.nrega.nic.in/netnrega/home.aspx.

The reason given for the delay is not listed in the above. It is given in two categories - "compensation not due" and "other".

\subsection{Impact of delay in wage payment}

Payment of wages in MGNREGA has been a major issue since the inception of the Act. In the past, lack of availability of funds has been cited as the major reasons in the failure of disbursement of wages on time. Though, this year the budget for the Act was highest ever, still, there have been headlines regarding failure to disburse wages on time. In Sanathpur, all the 28 workers got their payment lately with seven workers out of them getting their dues after 38 days.

This trend obviously impacts the behaviour of the workers towards the work. Two of the households that We talked to haven't been allocated work since more than two years. As a result, their sons moved out of village in search of labour work. To meet their needs, these workers do daily labours. In case of delay in wage paymentthey have no clue of the time period within which they will receive their payment. On asking one of the workers, who had worked in the past and had not applied to work this year, late payment was the answer We got. He did not apply for the work as he did not want to take risk. This is one of the major reason for lower demand of work under the Act.

\section{Other abnormalities in our findings}

In this section,Wewill highlight some of the abnormalities that We noticed while interviewing the MGNREGA workers in the village. 
Lack of awareness - Lack of awareness has been a major obstacle among the poorer sections of our society on their way to development. None of the workers were aware that they are entitled to delay compensation from sixteenth day onwards. Also, 80 percent of the workers who worked this year were not able to tell either the number of days they worked and the total amount they received for their work.

> Lack of financial inclusion- Out of 237 persons, only 73 have individual bank accounts out of which only 49 accounts are active and five joint accounts. Even most of the account holders do not check their bank accounts to ensure credit. A contradiction which We noticed was that 11 out of the 28 persons who worked denied of getting the payment for their work.

$>$ Allegation of partiality shown by the Gram Panchayat - Some workers alleged that the there is a partiality in case of the allocation of work in the village.

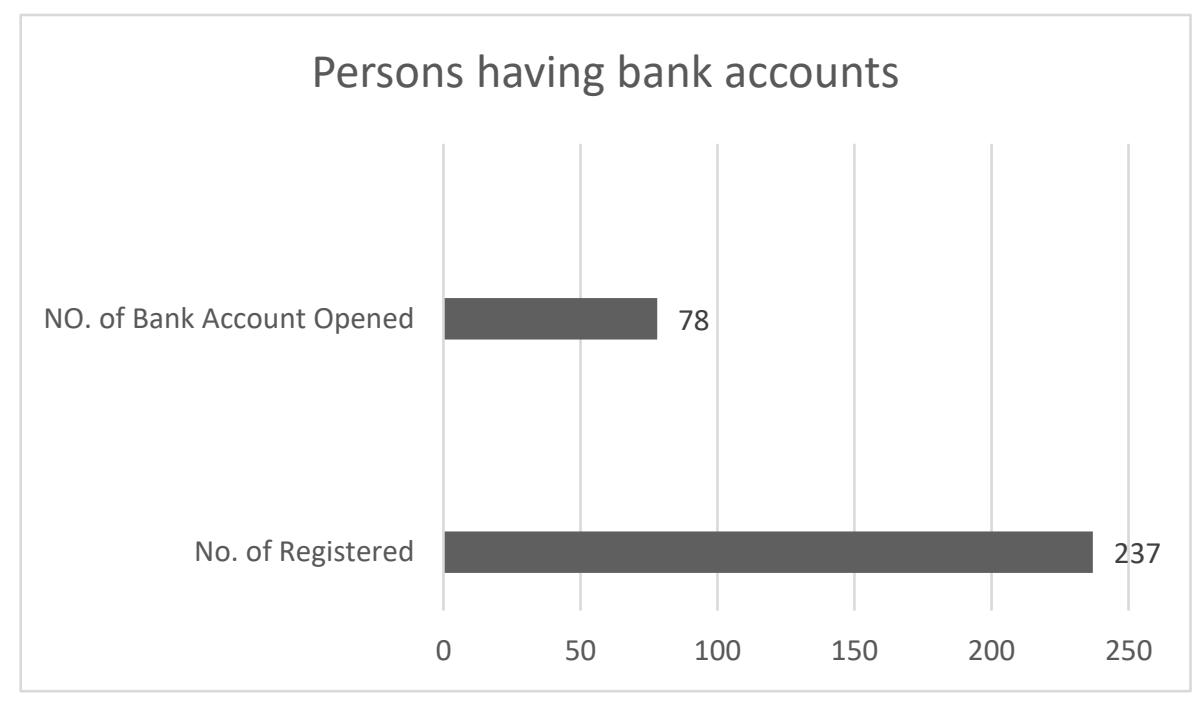

Figure 6. Persons having bank accounts

Source: Primary Data.

\section{Conclusions}

The funds allocation for MGNREGA this financial year was highest ever with 48,000 Crores INR. In spite of this allocation, there have been reports of the shortage of in the reent past. In a news in October 2018, it was stated that nearly 88 percent of the MGNREGA budget have already been exhausted.

MGNREGA is a demand driven program. Thus, the states often spent beyond the allocated amount. If we look at the last year allocation, it was 38,500 crore INR. Later, in the month of August and December, 8,999 INR crores was injected. The states of Andhra Pradesh, Telangana, Tamil Nadu and Kerala have exhausted their budget for the entire year due to uptake in MGNREGA work owing to drought or delayed rainfall. The demand for MGNREGA peaks during the period from November to March. The pending payments for the financial year 2016-17 was 7,000 crores INR, which would have come from current year's allocation. This trend will consequently leave less than allocated funds for the program to be successfully implemented.

\section{References}

1. Indira Bishnoi, Sarita Verma, Swati Rai (2012). MNREGA: An Initiative towards Poverty Alleviation through Employment Generation. Indian Research Journal of Extension Education Special Issue. Volume 1, January. https://scholar.google.co.in/scholar?hl=en\&as_sdt=0,5\&cluster=17681286830757140256

2. Government of India (2012). An Anthology of Research Studies on the MGNREGA: 2006-2012. Ministry of Rural Development. Orient Blackswan Private Limited. https://web.archive.org/web/20130921125532/http://nrega.nic.in/netnrega/writereaddata/Circulars/MGN REGA SAMEEKSHA.pdf. Accessed on Feb 15, 2020.

3. Sadhana Gupta, Subodh Kumar and Manoj Kumar (2017). Impact of MNREGA and level of awareness on Socio-economic profile of rural women in Faizabad district. Journal of Pharmacognosy and Phytochemistry, 6(6), 303-305. http://www.phytojournal.com/archives/2017/vol6issue6/PartE/6-6-81-460.pdf 
4. Praveen Gupt (2015). Millennium Development Goals through MNREGA. Journal of Political Sciences \& $J$ Public Affairs, S1. DOI: 10.4172/2332-0761.S1-002. https://www.semanticscholar.org/paper/Millennium-Development-Goals-through-MNREGAGupt/6a5a426d88424d62d35858f974193b735ff44108.

5. R. Sathishkumar, \& Kumar, D. K. R. (2020). Mgnrega's Evaluation and It' S Impacts on Rural Labour Market. Our Heritage, 68(30), 1663-1694. Available Online at: https://archives.ourheritagejournal.com/index.php/oh/article/view/3542

6. World Bank (2008). Social Audits: from ignorance to awareness. The AP experience. Available online at https://web.archive.org/web/20140315212637/http://www.newsyaps.com/nrega-effects-andimplications/ 101064/. Accessed on Feb 15, 2020.

7. Sarabjeet D. Natesan, Rahul Ratnakar Marathe (2017). Evaluation of MGNREGA: data envelopment analysis approach. International Journal of Social Economics; 44(2), 181-194. https://www.emerald.com/insight/content/doi/10.1108/IJSE-05-2015-0114/full/html

8. Tiwari, Rakesh et al. (2011). MGNREGA for Environmental Service Enhancement and Vulnerability Reduction: Rapid Appraisal in Chitradurga District, Karnataka, Economic and Political Weekly (EPW), May 14, XLVI (20), 39-47. https://www.jstor.org/stable/23018212?seq=1

9. Azam M. (2012). The Impact of Indian Job Guarantee Scheme on Labor Market Outcomes: Evidence from a Natural Experiment. IZA Discussion Paper No. 6548. https://papers.ssrn.com/sol3/papers.cfm?abstract id=1941959

10. Selvamani P. (2012). MGNREGP and Women's Participation in India. IJSR - International Journal of Scientific Research, 1(7), 38-41. https://www.worldwidejournals.com/international-journal-of-scientificresearch-(IJSR)/file.php?val=December_2012_1354295023_26e08_15.pdf

11. Magda Tsaneva \& Uttara Balakrishnan (2019). The Effect of a Workfare Programme on Psychological Wellbeing in India. The Journal of Development Studies, 55(12), 2593-2609. DOI: $10.1080 / 00220388.2018 .1502879$.

12. Gaiha R and Imai K. (2005). A Review of the Employment Guarantee Scheme in India . Policy Case Study: Labour Markets and Employment. Delhi and Manchester: Interregional Inequality Facility, University of Delhi and University of Manchester, June. http://hummedia.manchester.ac.uk/schools/soss/economics/discussionpapers/EDP-0513.pdf

13. Swamikannan, D. and G. Lakshmi (2011). Role of Women Beneficiaries in Mahatma Gandhi National Rural Employment Guarantee Programme - A Case Study. ECONSPEAK, 1 (4), 12-24. http://skirec.org/wp-content/uploads/2017/02/ECON-SPEAK-PAPER-2-5.pdf

14. Subbarao K (2001). Systemic Shocks and Social Protection. Role and Effectiveness of Public Works Programs. Africa Region Human Development Working Paper Series. Washington DC: World Bank https://openknowledge.worldbank.org/bitstream/handle/10986/11819/333510SSNPrimerNote1.pdf?se

15. Tata (2011). An evaluation of MGNREGA in Kerala; Tata Institute of Social Sciences. http://www.nregs.kerala.gov.in/images/studies/tiss.pdf

16. Reddy, Gangadhara Y and Aswath G.R. (2016). Performance of Mahatma Gandhi National Rural Employment Guarantee Act in Karnataka, India. International Research Journal of Social Sciences, 5(1), 15-19. http://www.isca.in/IJSS/Archive/v5/i1/3.ISCA-IRJSS-2015-271.pdf

17. Salian, Prasanna V. and D. S. Leelavathi (2014). Implementation of Mgnrega in Karnataka: Issues And $\begin{array}{lllll}\text { Challenges. Journal of Rural Development, } 33 & \text { (3), 261-279. }\end{array}$ http://nirdprojms.in/index.php/jrd/article/view/93269 